\title{
A LITERARY TEXT AND ITS CONCEPTUAL PERSPECTIVE IN THE CONDITIONS OF THE RUSSIAN-CIRCASSIAN BILINGUALISM
}

\author{
(C) Fatimet N. Khuako \\ Maykop State Technological University, \\ Maykop, Republic of Adygea, Russian Federation \\ fatimah2@mail.ru
}

The subject of the research is the Circassian aesthetics. The linguistic panorama of the Circassians carries the Russian-Circassian double-digit core, which explains the need to turn to the modern author's creation of a text from the standpoint of communication, taking into account the ethno-peculiar in concrete aesthetics. It is emphasized that the attention of researchers to the issues of mental thinking in the double-digit linguistic design of a literary text is increasing today. It is shown that in the bilingual Russian-Circassian space, throughout its existence, textual impregnation has been combined into the presentation of various expressive means, semantically saturated with the Circassian mentality, designated as "mental phrasemes". It is concluded that wordcreators, who are themselves native speakers of the national language, deliberately and systematically include in the text they produce, the corresponding expressive phrases, sometimes colloquial, but bearing the tonality necessary for the authors. The conclusion contains the idea that the modern Circassian author manages to consider in an artistic presentation philosophical truth that continue to fill mental interests to this day. As a methodology used in the study, the periodical comparison of the conceptual data available on the issue is mainly used, as well as the terminological analysis produced on its basis, which helps to capture an objective perspective of the problem with the involvement of textual illustrations.

Key words: literary text, ethnos, Circassian, bilingualism, mental phraseme.

\section{[Ф.Н. Хуако Художественный текст и его понятийный ракурс в условиях русско-черкесского би- лингвизма]}

Предметом исследования выступает черкесская эстетика. Языковая панорама черкесов несет русско-черкесскую двузначную сердцевину, чем объясняется потребность обратиться к современному авторскому созданию текста с позиций коммуникации, учитывая этно-своеобразное в конкретной эстетике. Подчёркнуто, что внимание исследователей к вопросам ментального мышления в двузначном языковом оформлении художественного текста сегодня усиливается. Показано, что в билингвальном русскочеркесском пространстве на протяжении всего его существования компонуется текстовое вкрапление в изложение разнообразных, семантически насыщенных менталитетом черкесов, выразительных средств, обозначаемых как «ментальные фраземы». Делается вывод, что словотворцы, сами являющиеся носителями национального языка, умышленно и планомерно включают в продуцируемый ими текст соответствующие выразительные обороты, порой просторечные, но несущие нужную авторам тональность. Заключение содержит мысль о том, что современному черкесскому автору удается рассмотрение в художественном изложении философских истин, продолжающих наполнять ментальные интересы и по сей день. В качестве методики, применяемой в исследовании, преимущественно используется периодическое сопоставление имеющихся по вопросу понятийных данных, а также производимый на его основе терминологический анализ, помогающий захватить объективный ракурс проблемы с привлечением текстовых иллюстраций.

Ключевые слова: художественный текст, этнос, черкес, билингвизм, ментальная фразема.

Fatimet N. Khuako - Ph.D. (Advanced Doctorate) in Philology, Professor, Maykop State Technological University, Maykop, Republic of Adygea, Russian Federation.

Хуако Фатимет Нальбиевна - доктор филологических наук, профрессор, Майкопский государственный технологический университет, г. Майкоп, Республика Адыгея, Российская Федерация. 


\section{The Introduction}

Generally known in science is the recognition that language as a linguistic system is at the personal disposal of the individual (its native speaker). As a result of this phenomenon, any worldview or ideology that focuses on the individual as a concentrate of a particular culture is aimed at absorbing linguistic constructions. The research works of the following linguists have had a significant impact on the consideration of the adjacent spaces in this case: N.D. Arutyunova (corresponding member of the USSR Academy of Sciences of the twentieth century), A. Wierzbicka (Poland, the twentieth century), E.A. Zemskaya (The Institute of Russian Language of the Russian Academy of Sciences named after V.V. Vinogradov, XX century), V.I. Karasik (Pushkin State Institute of Russian Language, modernity), A.A. Leontiev (full member of the RAO and APSN, XX century), G.G. Pocheptsov (Ukraine, XX century) and others. Such works are based on aspects of social linguistics, linguistic cultural studies, language communication, psychological linguistics, linguodidactics, etc.

Interpersonal relationships of a person are mainly caused by the periodic decoding of coded structures that carry information about the controversial nature of the mutual influence of communicants. To date, the perspective of the conflict is considered within the humanitarian sphere, which focuses on formulas that contradict intra-linguistic laws, and on the patterns of conflicts in speech acts, that is, we are talking about linguistic conflict. Today's linguistic lines touch on issues raised by such a result of human production as a literary text. Both in fiction and in journalistic prose, this expansion is most noticeable today due to the widespread mediatization of reality (and, in particular, culture). As a result of the obvious spread of media spaces, the coded constructions named at the beginning of the paragraph have become an active mechanism of society, which has not only taken a confident position next to education, home, and politics, but also displaces them. Global culture as a resource of value priorities is made up of pearls acquired chronically, from the aesthetic successes of a certain ethnic group. In this regard, we consider Circassian aesthetics as an example in this work. The Circassian language panorama carries a polylingual field, where scientists confidently identify the Russian-Circassian two-digit core, which is common in the geographical territories of native speakers. Accordingly, there is a need to look at the current mechanism of the author's creation of the text from the perspective of modern communication, and this, perhaps, will give the conceptual content a more specific, as well as a somewhat clarifying generalization. Thus, the study of the theory of literary text still retains its current prospects in today's linguistics. At the same time, the consideration of the ethno-peculiar in a specific (for example, in Circassian) aesthetics remains no less topical in didactic, theoretical, and applied perspectives. Thus, at the present stage, the attention of researchers to the issues of mental thinking in the two-digit language design of a literary text is increasing.

\section{Research methods}

As a method used in the study, the periodic comparison of the available conceptual data on the issue is mainly used, as well as the terminological analysis produced on its basis, which helps to capture an objective perspective of the problem, sometimes with the involvement of text illustrations.

\section{The main part}

In any of the text copies of the general planetary scale, professional artistic reproduction of absolutely ethnic characteristics of the characters is usually found, while emphasizing the traditional conditions of the chronically conditioned environment acquired by a separate ethnic group. Such an atmosphere, which is conducive to creativity, penetrates through the producing pores of the active word-maker, who respects and reveres, and therefore presents with his work the outstanding trends of his own native aesthetics. As happened in the postSoviet society at the turn of the century, at the end of the "perestroika", organized directly by 
the liberals who worship the cult of the book, the spiritual-value and aesthetic limits at once increased, sometimes losing any restrictions. Such transformations contributed to the activation of universalism, which today acts as a comprehensive base of value priorities accumulated by the population of the planet. The universalization that is gaining momentum in this way actually becomes difficult: the distinctive characters and aesthetic priorities of individual ethnic groups in the general global field turn out to be significantly significant. In the postperestroika period, the complex, then perceived as a whole, culture, accompanied by a clearly unified public, was noticeably divided. Noticeably isolated, some aesthetic group modifications are formed, which make up both professional (up to elite) and mass thresholds. The standard norm between them has acquired almost zero positions. At the same time, the placement of visible character characters in the texts was carried out by quoting the described characters belonging to specific ethnic cultures. Since the harmony of this culturelike, independent and multi-faceted subject lies precisely in the popular reproduction of certain planetary priorities inherent in many civilizations. Moreover, in order to reproduce the situational situation necessary for literary texts, not only the phrase inherent in a particular character must be taken into account, but also the reactions generated by it, that is, the emotions accompanying the subtext, allocated to such a field of linguistics as emotiology. Therefore, the emotive aspect of interpersonal communication is studied in the works of such Russian and foreign humanitarians of science as I.V. Arnold, E.S. Aznaurov, D. Goleman, V.I. Shakhovsky, etc., who demonstrate the importance of emotions in a communicative act. However, in particular, the textual emotivity of statements (especially artistic ones) has not been practically studied.

As we have already noted above, a literary text is a rather complicated subject of study in terms of concepts. The heterogeneity of actually many available terminological formulations, illustrated below, is a kind of conditional sign of this concept in all its uncertainty. We will try further to roughly systematize the existing definitions of a literary text into three group subspecies: 1) a set of text units with specific properties (L.A. Isayeva); 2) a number of definitions of the text based on the function of reflection of reality ("the inner state of the artist" [1, p. 120] from V.G. Admoni, a combination of "reflection of the objective world and the author's fiction" [11, p. 13] from Z.Ya. Turaeva, a system "all elements of which are in close interaction and are oriented by the author's point of view to the transmission of certain aesthetic and cognitive information" [6, p. 5] from D.M. Magomedova and M.I. Gorelikova); 3) the text as a verbal message going through the channel of the genre a single complex whole" [2, p. 41] in I.V. Arnold or "characterized by semantic and structural completeness and a certain attitude of the author to the reported" [9, p. 4] in L.M. Loseva. Thus, based on such ambiguity of textual terminology, it is permissible, without assuming the responsibility of the final formulation, to limit ourselves to the categories that make up the text, that is, what is somehow related to faith, to justice, to positivity, to the facts of events and much more. In relation to this aspect, much that is duplicated and displayed acts as both a tool and a resource. According to the correct comment of V.I. Shakhovsky, without taking into account the emotive space, no communication study can be fruitful, since "emotions are an integral part of a person and his speech activity, this is one of his most important characteristics, because through the linguistic expression of emotions, the person himself is known as a linguistic personality" [13]. So, for example, I. Halperin distinguishes such, often emotively based, textual qualities as modal (that is, tonally colored) completeness (that is, the completeness of the author's opinion), which is related to the statements that make up the text. Therefore, it is quite natural that the philologist of the first half of the last century $O$. Mandelstam confidently stated the following in relation to the literary text: genuine "poetry, as a whole, is always directed to a more or less distant, unknown addressee" [10, p. 150]. T.G. Khazagerov emphasizes such textual qualities of works as: first, a single, indivisible structural integrity (close to the above-mentioned completeness); second, emotional and figurative fullness; third, "a special power of influence" 
$[12$, p. 50] (that is, the specific power of the generated reactions). It is in accordance with the latter feature that the followers of the aesthetic dialogue of the reader with the author (that is, receptive aesthetics), one of the basic canons of their teaching, do not represent a real dialogue with a real interlocutor, but a portrait of a virtual interlocutor, that is, a reader just figurative.

In addition, it is the artistic text that has, in addition to the general text properties characteristic of any text product, also a number of specific qualities that are mandatory only for it. Among these, L. Isayeva refers to the following: "the obligatory presence of a hidden semantic layer, expressed both by linguistic and non-linguistic means; the aesthetic function of such hidden meanings; semantic polysemy, multilayered literary text; the multiplicity of semantic interpretations of a literary text, with the identity of its "invariative" creation; the diversity of carriers of hidden meanings of a literary text: they are any units-from sound to text" [7, p. 43]. Such a possibility of such a subtext, which is characteristic of the text in general, is able to come to the fore and open up only in the event background (including communication acts). Speech communication is necessary in this case, since there are not so many actual spaces of communication in artistic word-making. Tactical speech techniques can be implemented either in groups or in the masses. However, in contextual situations, both interpersonal and individual - personal interactions are quite acceptable for literary characters. This aspect involves the participation in the process not only of the specified language components that came out from the pen of the author, but also the appearance of other verbal products of the recipient, which are quite remote from the sender, reacting to what is read. That is why I. R. Halperin in his own monographic work [5], devoted to the text as a linguistic phenomenon, puts forward a set of text-forming features, proclaiming among them units both semantically rich and figuratively constructed, while not forgetting to emphasize the mutual dependence of both groups. While receiving the text, the interpersonal (sender-receiver) and internal (textsubtext) panels merge. This happens because any textual presentation is such a fusion, in the harmony of which, between the lines, it is possible to trace another, albeit implicit, but still meaning, carried by the so-called context.

In this case, the text in its understanding deepens, becoming any integral figurative and symbolic structure, as a result of which not only literature, but also the directions related to art are instrumentally based on the texts of musical and theatrical creativity. Therefore, the word that forms the text is not just a carrier, but also a coordinator of the displayed resource. Thinking about thoughts, worrying about feelings, saying things about things said, telling stories. All this, based on the inner world of the individual, distinguishes the natural and exact sciences from the humanities, but there are no unbreakable, hopeless limits here. At the same time, every text is essentially a logically sustained set, in which other statements of thoughts act as constructing puzzles. In addition, according to L.A. Isayeva, "a literary text, due to the special nature of the functions performed - is not just a means of "communication", "information", but a unit of creating a "new aesthetic reality" [7, p. 38], which to some extent is beyond the boundaries of literary studies and linguistics.

In fact, in the bilingual (for example, in the Russian-Circassian) space, throughout its existence (including today), a textual interspersion is formed in the presentation of various, semantically saturated with the Circassian mentality, expressive means, designated by M.P. Akhidzhakova as "mental phrasemes". At the same time, the stated thought is awakened as a thought about extraneous reflections, other people's opinions, positions, statements, signs, behind which there is a god who reveals himself (confession) or persons who carry authoritative canons, the requirements of great-grandfathers, wise folk aphorisms, and so on. How does the modern researcher of Russian-Circassian bilingualism characterize this phenomenon? Bagirokov, "Thus, the "mental phraseme", "mental lexeme", "mental mythologeme", functioning in the literary text of a bilingual language personality, are able to create a contrast to the rest of the text" [3, p. 168-169]. So, for example, if you take only one fragment from the 
story of the modern author Asfar Kuek "Oak Leaf" (Maykop, 2007), easily finding such phrasal combinations in it, you can clearly trace the percentage of the presence of a mental phraseme in it. This is the monologue of the elder of the two talking heroes, who convinces his interlocutor of the obvious, age-old wisdom of ethnic ancestors (emphasis - ours, F.H.): "A man heard two trees talking to each other in the forest. One says to the other: "There is no bad place for a homestead, there is a bad joint. The one who makes it out of me will live happily ever after". The second tree responds: "I am a tree that brings trouble, so a good joint will not come out of me...". When the old woman and I began to build, she chose trees for the jambs. I showed them to her, and she chose them, and she guessed right - all the joints were good". "However, a tree is a tree, it all depends on the person. If I hadn't met a good person, my doorposts wouldn't have become good themselves. I know people who are well versed in trees, and their homes have not become kind. It all depends on the woman. If you come across an unkind woman, write, it's gone. If you have a good wife, do not go to weddings, you yourself have a wedding every day, if you married a bad girl, do not go to someone else's funeral, you yourself will have a funeral every day in the house" [8, p.20]. As can be clearly seen from 97 words out of 161 lexical units of the given example, the predominant number of components that make up the presentation in this paragraph are convincingly related to the number of phrases of the Circassian mentality.

Or, for example, you can freely accept the dialogue (178 words) of the two central characters in the novel "Jem and Helen" by another modern Circassian author Inal Chatao (Maykop, 2013). According to the exchange of several phrases (60 words), here you can clearly trace the specifics of the characterological mentality of the nation, including the specific personal qualities of a man striving for the guardianship of the weaker sex and a woman guided by a strict society in her actions (emphasis-nashi, F.H.): "Jem got up and walked along the terrace, the sea away from the shore already looked a little greener. She didn't want to smoke, and she probably expected Jem to keep it up. "We've completely forgotten about the girls, Helen, it's long past breakfast time. Let's. We'll make breakfast, it's late. - Didn't we leave the cooking to the girls?" Helen asked. - Yes, it was like that. But because their mother has spoiled them, they ignore their responsibilities. - You're made for people to fall in love with, I see". And kind, and funny, and wise, and witty, and talented... - You made me some kind of saint from the Scriptures. - But you are Saint Jem of Marmaris." - Yes, a great man, a hundred and seventy feet tall, sixty-eight pounds - "'No, Jem, I mean, you're a great writer. "Oh, that's it. You should also read my critics, who just tear me to shreds. For them, I'm not even a writer, but a scribbler. Let's leave it at that, I'll make breakfast and you wake the girls up. They didn't come here to sleep. If it's hard for you, I can handle it. A bucket of water is quite enough for this" [13, p. 72].

The word-makers A. Kuek and I. Chatao, who consider themselves to be Circassian ethnos, who are themselves native speakers of the national language, deliberately and systematically include in the text produced by them the appropriate expressive turns, sometimes colloquial, but carrying the tonality necessary for the authors. The stylization of texts with criticism of their understatement, which is intellectually grounded and technically sustained in the new century, is a paradigm already present in artistic creativity, which has formed a conditional turn of humanitarian perception towards hesitation and doubt. Initially, the artistic presentation continues to need a sincere reader's trust, which is expected in the course of perception on the part of the recipient of attempts to interpret the author's messages.

\section{Conclusion}

Today, in the language environment, the core communication tactics that make up communication acts are mainly determined by the culture of both mass and ethnic. Didactic efforts on semantic richness, clarity, imagery and consistency of utterances are poorly concentrated in the educational environment today. The factors and conditions of speech fullness of the student's everyday environment are overlooked by science, and the configura- 
tions of their communication employment outside the school walls are not developed. Moreover, this ratio is often dominated by the power of mass culture (in particular, "pop") it can be considered newly acquired in the post-Soviet period. In the official Soviet aesthetics, text statements that please any, often completely uneducated audience, would be perceived as unacceptable violations and, accordingly, prohibited. Soviet education, which glorified the standard well-read individual in the ideological canons, focused most of the population on this ideal through cultural and educational work. This absolutely does not happen today, which is emphasized by the Circassian author A. Kuek, whose narrator is unpleasantly surprised by the cult layout in the minds of the new generation: "Yes, young people do not think about this today, they sit carelessly, live for their own pleasure and think that they will never grow old. But the time comes and life puts everything in its place, you do not know when and how it will give such a lesson, after which you begin to see a lot of things in a completely different way. Everyone grows up in their own way. If he learns from his elders, he matures in time, but if he learns from life only from his mistakes, he matures late. And if you're late, you'll be trailing behind. He will be overtaken by those who follow him, if he threw clods of dirt at the elders, stones fall into him. Yes, there is no better educator than time..." [8, p. 219]. In this respect, the modern author manages to consider in the artistic presentation of philosophical truths, cults, mandatory from time immemorial for the North Caucasian Mountain peoples, which continue to fill the mental interests to this day. At a minimum, this determines a certain spiritual standard that needs mandatory attention from representatives of society. Thus, there is a global mentality common to many ethnic groups, which is often understandable to a representative of any planetary people.

\section{Conclusions}

Thus, no matter what our research intentions were, the initial object of study in our thematic case could only be the text, with all the variability of its forms, categories and features. Moreover, in the bilingual space, a clearly noticeable textual community is one of the core features at the same time as the logic, imagery and completeness of artistic thought. It is in such a categorical environment that today's recipient, who enters into interaction with the author of a work of art, equally belonging to any (including Circassian) ethnic group, can immerse himself. As the classic of Russian linguistics M. Bakhtin says about our object, "We do not intend to delve into the history of the humanities, and in particular philology and linguistics, - we are interested in the specifics of humanitarian thought, aimed at other people's thoughts, meanings, meanings, etc., realized and given to the researcher only in the form of a text" [4, p. 298]. The presence of mental specificity in literary texts of the bilingual (RussianCircassian) language environment demonstrates: to the universal global world landscape, a personal author's frame is added, carrying selectively developed verbal meanings that spread the ethno-cultural experience of previous civilizations.

\section{Лumepamypa}

1. Адмони В.Г. Система форм речевого высказывания. СПб: Наука, 1994. 151 с.

2. Арнольд И.В. Стилистика современного английского языка (Стилистика декодирования). 3-е издание. М.: Просвещение, 1990. 300 с.

3. Багироков $X$. Художественный билингвизм как полилингвальное пространство: к постановке проблемы // Вестник науки АГУ. 2012. № 2. С. 166-170.

4. Бахтин М. Проблема текста в лингвистике, филологии и других гуманитарных науках. Опыт фрилософского анализа // Бахтин М.М. Эстетика словесного творчества / Сост. С.Г. Бочаров. Изд. 2-е. М.: Искусство, 1986. С. 297-325.

5. Гальперин И.Р. Текст как объект лингвистического исследования. М.: Наука, 1981. $140 \mathrm{c}$. 
6. Гореликова М.И. Магомедова Д.М. Лингвистический анализ художественного текста. М.: Русский язык, 1989. 126 с.

7. Исаева Л. Художественный текст: скрытые смыслы и способы их представления. Краснодар: Краснодарское книжное издательство, 1996.

8. Куек А. Танцы на рассвете. Майкоп: Адыгейское республиканское книжное издательство, 2007. 360 с.

9. Лосева Л.М. Как строится текст. М.: Просвещение, 1983. 93 с.

10. Мандельштам О.Э. Сочинения: в 2-х тт. Т. 2. М.: Художественная литература, 1990.

11. Тураева 3.Я. Лингвистика текста. М.: Просвещение, 1986. 127 с.

12. Хазагеров Т.Г. Экспрессивная стилистика и методика анализа художественных текстов // Проблемы экспрессивной стилистики. Выпуск 2. Ростов-на-Дону, 1992

13. Чатао И. Джем и Элен. Роман. Майкоп: Полиграф-ЮГ, 2013. 208 с.

14. Шаховский В.И. Эмотивная семантика слова как коммуникативная сущность // Коммуникативные аспекты значения. Волгоград: Волгр. пед. ин-т, 1990. URL: http:// www.russcom.ru/rca_biblio/sh/shakhovsky02.html

\section{References}

1. Admoni V.G. Sistema form rechevogo vyskazyvaniya [The system of forms of speech utterance]. Saint Petersburg: Nauka, 1994. 151 p. (In Russian).

2. Arnold I.V. Stilistika sovremennogo angliyskogo yazyka. (Stilistika dekodirovaniya) [The stylistics of modern English. (Decode stylistics)]. 3-ye izdaniye. Moscow: Prosveshcheniye, 1990. 300 p. (In Russian).

3. Bagirokov $K h$. Khudozhestvennyy bilingvizm kak polilingvalnoye prostranstvo: k postanovke problemy [Artistic Bilingualism as a Multilingual Space: Towards a Problem Statement]. Vestnik nauki AGU. 2012. No. 2. pp. 166-170 (In Russian).

4. Bakhtin M. Problema teksta $v$ lingvistike, filologii i drugikh gumanitarnykh naukakh. Opyt filosofskogo analiza [The problem of the text in linguistics, philology and other humanities. The experience of philosophical analysis]. Izd. 2-ye. Moscow: Iskusstvo, 1986. pp. 297-325. (In Russian).

5. Galperin I.R. Tekst kak objekt lingvisticheskogo issledovaniya [Text as an object of linguistic research]. Moscow: Nauka. 1981. 140 p. (In Russian).

6. Gorelikova M.I. Magomedova D.M. Lingvisticheskiy analiz khudozhestvennogo teksta [Linguistic analysis of literary text]. Moscow Russkiy yazyk. 1989. 126 p. (In Russian).

7. Isaeva L. Khudozhestvennyy tekst: skrytyye smysly i sposoby ikh predstavleniya [Fictional text: hidden meanings and ways of their presentation]. Krasnodar: Krasnodarskoye knizhnoye izdatelstvo, 1996. (In Russian).

8. Kuek A. Tantsy na rassvete [Dancing at dawn]. Maykop: Adygeyskoye respublikanskoye knizhnoye izdatelstvo. 2007. 360 p. (In Russian).

9. Loseva L.M. Kak stroitsya tekst [How the text is constructed]. Moscow: Prosveshcheniye, 1983. 93 p. (In Russian).

10. Mandelstam O.E. Sochineniya: v 2-kh tt. [Works: in 2 vols.]. V.2. Moscow: Khudozh. lit., 1990. (In Russian).

11. Turaeva Z.Ya. Lingvistika teksta [Linguistics of the text]. Moscow: Prosveshcheniye. 1986. 127 p. (In Russian). 
12. Khazagerov T.G. Ekspressivnaya stilistika i metodika analiza khudozhestvennykh tekstov [Expressive stylistics and methods of analysis of literary texts]. Problemy ekspressivnoy stilistiki. V. 2. Rostov-on-Don. 1992. (In Russian).

13. Chatao I. Dzhem i Elen. Roman [Jem and Helen. Novel]. Maykop: Poligraf-YUG. 2013. 208 p. (In Russian).

14. Shakhovsky V.I. Emotivnaya semantika slova kak kommunikativnaya sushchnost [Emotive semantics of a word as a communicative entity]. Kommunikativnyye aspekty znacheniya. Volgograd: Volgrogradskiy pedogagicheskiy institut, 1990. Available at: http:// www.russcom.ru/rca_biblio/sh/shakhovsky02.html (In Russian). 